\title{
Evaluation of Organic Matter in the Yamama Formation at West Qurna Oil Field, Southern Iraq
}

\author{
Abdul-Mutalib H. Al-Marsoumi \\ College of Science \\ Basrah University
}

\author{
Abdul-Wahab D. Salman \\ South Oil Company \\ Basrah
}

\author{
Rafed A. Al-Mohamed \\ College of Science \\ Basrah University
}

(Received April 18, 2004 , Accepted September 28, 2004)

\begin{abstract}
Yamama Formation (Valanginian-Early Hauterivian) carries a special economic importance, since it represents one of the well known oil reservoirs southern Iraq. To evaluate the organic material contents of this formation an organic geochemical study was conducted. A total of 58 out of 227 previously collected and described core samples were analysed using pyrolysis method; these samples represent five oil wells which are distributed over West Qurna (WQ) field.

The organic material of the selected samples were separated then analyzed using Rock-Evaltechnique.The organic geochemical data confirm that the Yamama rocks of WQ field represent a source rocks that posses a poor to very good properties depending upon the quantitative evaluation of petroleum potential (PP) and total organic carbon (TOC). The source rocks were thermally matured except in some few samples found at depth below $3700 \mathrm{~m}$. These samples were exceeded the maturation stage leading to the formation of pyrobituminous layer of variable thickness. Most of Yamama organic matters were related to type II kerogen that produces oil and gas prone. Few samples are related to type III kerogen that produces gas prone.
\end{abstract}

\section{قييم المالة المضوبة لكون اليمامةف جظل فط غرب الفرنة جنوي المرق}

\section{المالخص}

تكوين اليملمة (الفالنجنيان -الهاوتريفي المبكر) ذو أهمية اقتصاية كونه يمل لُحد المكلمن الرئيد ـة

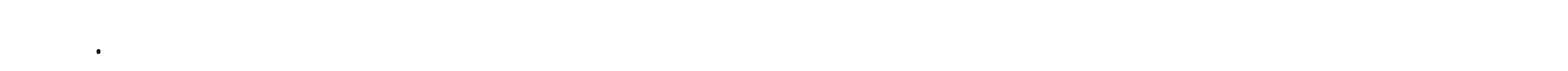

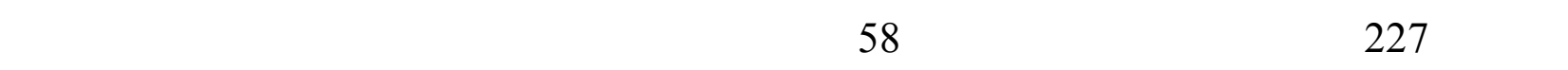
خمسة آبار موزعة على تركيب حمل غرب القرنة.المواد العضوية في النماذج المختارة فصلت ثم حللت بقنية ققيم الصخور.

نتائج الجيوكيمياء العضوية أثبتت ان صخور تكوين اليملمة في هقل غرب القرنة تمذ لل ص خور

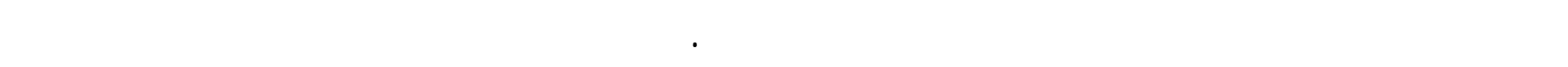


والكمية الكلية الكاربون العضوي فلن المواد العضوية لهذا التكوين قد بلغت ظاق مقق دم م ـن النض -وج

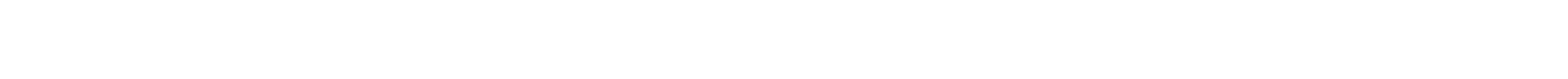

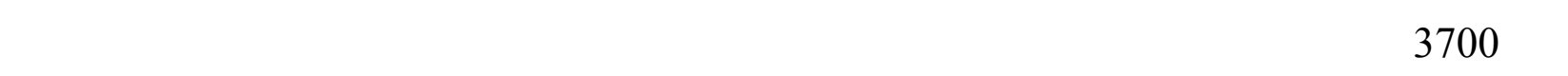

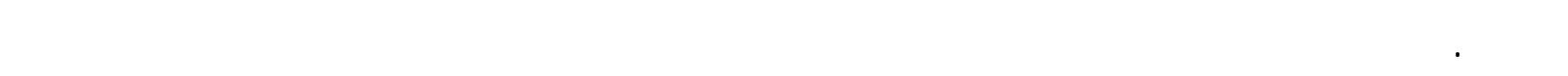

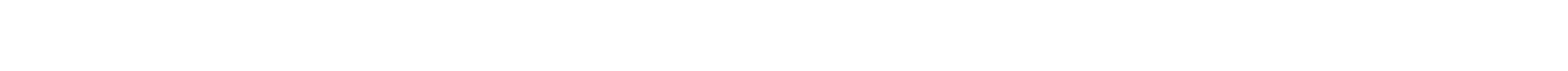
للهيدروكاربونات الغازية.

\section{INTRODUCTION}

West Qurna field (WQ-field) represents one of the commonest oil fields at southern Iraq. This field is located about $70 \mathrm{Km}$ northwest of Basrah city (Fig.1), Previous seismic survey demonstrated that WQ-field is composed of an elongated double plunging asymmetrical anticline trending in a northwest-southeast direction. According to the tectonic subdivision, WQ- oil field occurs in Zubair subzone in Mesopotamia zone (Buday and Jassim, 1987). Yamama Formation represents one of the most widely distributed formations in Iraq and neighboring area. It is one of the most important oil production reservoirs in southern Iraq that extends from Valanginian- Early Hauterivian within the main retrogressive depositional cycle (Berriasian-Aptian) south of Iraq (Buday, 1980). Yamama Formation consists mainly of fragmental limestone with wide lateral lithological variation (Van Bellen, et al., 1959).

Fig.1: Location map of the study area. 
Unfortunately, large numbers of Iraqi oil reservoirs are suffering from lack in the studies dealing with the origin, distribution and maturation of their organic matter. The aim of the present study is to shade light on the origin, behavior, preservation and maturation history of Ymamam Formation organic matter.

\section{METHODOLOGY}

To conduct the present organic geochemical study 227 core samples were collected from ten oil wells in WQ-field. These wells were randomly distributed over the WQfield; the collected samples were firstly described, and then the organic matters in 58 core samples from five wells were analyzed. The organic materials (bitumen) were firstly extracted by Soxhallate method, then analysed by the column chromatography method after the separation of sulfur by melgem solution (Espitalie, 1986), and the separation of asphalt and organic material by $4.6 \mathrm{~mm}$ sieve. After the separation of light components (Aliphatic and Aromatic) and heavy components (Resins and Asphaltene), the Gas Chromatography (GC) was used for the determination of aliphatic components especially $\mathrm{C}_{15}-\mathrm{C}_{33}$ (Rulkotter et al., 1984). Moreover Rock-Eval technique (Banrajee and Shrama, 2002) was also employed for quantitative evaluation of Yamama rocks under study, this technique supply us with S1, S2, and TOC parameters, where S1 and S2 refer to the amount of Hydrocarbon (HC) in milligram per gram of solid rock $(\mathrm{mgHC} / \mathrm{g}$ rock) released when the kerogen thermally breaks up at $250-350 \mathrm{C}^{\circ}$ and $350-600 \mathrm{C}^{\circ}$ respectively. TOC refers to the total organic carbon in weight $\%$ in the soild rocks. The Tmax, which reflects the maximum temperature accompanied the generation of maximum amount of hydrocarbon (S2) was also obtained. The values of Hydrogen Index (HI), Production Index (PI), and Petroleum Potential (PP) were estimated following the method suggested by Langford and Blance-Valleron, (1990). Eventually, logging charts were used for the determination of the geothermal gradient in WQ-field.

\section{RESULTS AND DISDUSSION}

The color of the Yamama rocks ranges between pale yellow to black; this variation in colour related to occurrences of light, heavy, and mixed hydrocarbons and bitumen with different percentages in Yamama rocks. Pratt, (1984) pointed out that the preservation of organic matter needs quiet conditions, therefor the absence of bioturbations structures within the studied cores, and the low detrital supply as shown by Al-Marsoumi et al., (2003) bears witness of the well preservation of organic matter within Yamama sediments.

Most organic matter in non-reservoir rocks consists of kerogen, which is nothing but a mineraloid matter of indefinite composition. This material forms the main source of hydrocarbon after the break down of its complex chemical composition by heating (Levorsen, 1967). Kerogene is of different types, it could be derived from plants or animals or both, many authors have been classified kerogene and in the present study Banerjee and Sharma, (2002) classifications is adopted. The graphical representation of Hydrogen index (HI) verses Tmax. (Fig. 2) clarify that the majority of Yamama organic matter belongs to type II of kerogen which resembles most the of middle east oil as shown by Al-Sakini, (1992), this type of kerogen derived from marine organisms of both types plants and animals that produce oil and gas prone. Few samples belong to type III of kerogen which is originated from terrestrial plants that yield gas prone. 
The geothermal gradients play an important role in source rocks maturation, and the variations of temperature with depth were plotted in Figure (3). The estimated value of geothermal gradient in WQ-field is $2.7 \mathrm{C} / 100 \mathrm{~m}$ (Salman, 2003), and the increase in the geothermal gradient is constant with depth down to $3700 \mathrm{~m}$, then sharply increases

Fig.2: Classification of Yamama organic matter based on Tissot et al., 1987.

(Fig.3). The recorded temperature at the top of Yamama Formation ranges between 90$95^{\circ} \mathrm{C}$ and increases to $110-115^{\circ} \mathrm{C}$ at the bottom of this formation. The recorded high temperature of Yamama Formation in the WQ-field is related to one or more of the following factors. The secondary cracking of hydrocarbons yielding additional quantities of hydrocarbons, owing to the limited space within the Yamama rocks, an abnormal pressure will set up causing the high Yamama reservoir temperature. The type of kerogen, and the presence of anhydrite beds within Gotina Formation (Upper Jurassic) beneath Yamama Formation, since anhydrite is characterized by its high thermal conductivity (Levorsen, 1967). 
Fig.3: Geothermal gradient at West Qurna field.

Based on Espitalie et al. (1986) the obtained Tmax values (Table 1) indicate that the Yamama organic matters are thermally matured and reach an advance stage of organic matter maturation, except in some few samples especially those found at depth below $3700 \mathrm{~m}$, where the Yamama source rocks have exceeded the maturation stage (metagenesis) leading to the development of the pyrobituminous layer of variable thickness. The thickness decreases from $60 \mathrm{~m}$ at the flank to few meters at the crest of WQ structure. Following Basken, (1997) classification, the organic content of Yamama rocks could be categorized as good to very good owing to their TOC contents (Table 1).

Although large numbers of rocks are rich in TOC but this does not mean in any way that they can generate high quantities of hydrocarbon. The graphical representation of TOC versus petroleum potential (PP) gives ample information regarding productivity of the rocks. Figure (4) shows that Yamama Formation in WQ-field represents source rocks with good to very good grade. This conclusion is supported by the presence of pyrobitumen resulted from the secondary cracking of the Yamama hydrocarbons. 
Table 1: Max, min., and mean of TOC, S1, S2, HI, PI, PP, and Tmax. of Yamama organic matter. $\mathrm{T}=\mathrm{Wt} \%, \mathrm{~S} 1$ and $\mathrm{S} 2=\mathrm{mg} / \mathrm{g}, \mathrm{HI}=\mathrm{mg}$ hydrocarbon $/ \mathrm{g} \mathrm{TOC}$, $\mathrm{PP}=\mathrm{Kg}$ hydrocarbon $/ \tan$ of rock, Tmax. $=\mathrm{C}^{\circ}$

\begin{tabular}{|c|c|c|c|c|c|c|}
\hline \multicolumn{2}{|c|}{ Well No. } & \multirow{2}{*}{$\begin{array}{l}\mathbf{1}, \mathbf{n}=\mathbf{1 0} \\
1.07 \\
\end{array}$} & \multirow{2}{*}{$\begin{array}{l}\mathbf{2}, \mathbf{n}=15 \\
1.11\end{array}$} & \multirow{2}{*}{$\begin{array}{l}3, n=14 \\
1.74\end{array}$} & \multirow{2}{*}{\begin{tabular}{|l|}
$4, \mathrm{n}=9$ \\
1.17 \\
\end{tabular}} & \multirow{2}{*}{$\begin{array}{l}5, n=3 \\
2.57\end{array}$} \\
\hline \multirow{3}{*}{$\begin{array}{l}\text { TOC } \\
\text { wt } \%\end{array}$} & \multirow{3}{*}{$\begin{array}{l}\text { Min. } \\
\text { Max } \\
\text { Mean }\end{array}$} & & & & & \\
\hline & & 11.63 & 27.16 & 79.4 & 17.77 & 4.27 \\
\hline & & 3.828 & 10.34 & 14.99 & 4.96 & 3.28 \\
\hline \multirow{3}{*}{$\begin{array}{l}\mathrm{S} 1 \\
\mathrm{mg} / \mathrm{g}\end{array}$} & \multirow{3}{*}{$\begin{array}{l}\text { Min } \\
\text { Max } \\
\text { Mean }\end{array}$} & 0.26 & 1.22 & 0.24 & 0.54 & 1.25 \\
\hline & & 5.78 & 22.26 & 26.05 & 10.61 & 6.2 \\
\hline & & 2.438 & 7.50 & 6.379 & 3.106 & 4.2 \\
\hline \multirow{3}{*}{$\begin{array}{l}\mathrm{S} 2 \\
\mathrm{mg} / \mathrm{g}\end{array}$} & \multirow{3}{*}{$\begin{array}{l}\text { Min } \\
\text { Max } \\
\text { Mean } \\
\end{array}$} & 1.14 & 2.5 & 2.97 & 1.44 & 2.58 \\
\hline & & 19.69 & 60.11 & 141.05 & 23.98 & 8.62 \\
\hline & & 6.193 & 13.379 & 21.206 & 7.029 & 5.936 \\
\hline \multirow{3}{*}{$\mathrm{HI}$} & \multirow{3}{*}{$\begin{array}{l}\text { Min } \\
\text { Max } \\
\text { Mean } \\
\end{array}$} & 76 & 81 & 79 & 113 & 86 \\
\hline & & 285 & 225 & 260 & 196 & 335 \\
\hline & & 181.8 & 146.53 & 139.214 & 146.44 & 192.33 \\
\hline \multirow{3}{*}{ PI } & \multirow{3}{*}{$\begin{array}{l}\text { Min } \\
\text { Max } \\
\text { Mean }\end{array}$} & 0.05 & 0.08 & 0.05 & 0.08 & 0.33 \\
\hline & & 0.58 & 0.48 & 0.48 & 0.58 & 0.48 \\
\hline & & 0.131 & 0.306 & 0.293 & 0.322 & 0.393 \\
\hline \multirow{3}{*}{ PP } & \multirow{3}{*}{$\begin{array}{l}\text { Min } \\
\text { Max } \\
\text { Mean }\end{array}$} & 1.49 & 3.72 & 3.41 & 0.09 & 3.83 \\
\hline & & 25.47 & 72.37 & 167.1 & 34.59 & 13.77 \\
\hline & & 8.66 & 17.288 & 27.329 & 9.556 & 10.137 \\
\hline \multirow{3}{*}{ Tmax } & \multirow{3}{*}{$\begin{array}{l}\text { Min } \\
\text { Max } \\
\text { Mean }\end{array}$} & 431 & 442 & 434 & 377 & 432 \\
\hline & & 460 & 450 & 452 & 455 & 447 \\
\hline & & 440.5 & 446.333 & 446.643 & 440 & 439.67 \\
\hline
\end{tabular}

The hydrocarbons are characterized by their tendency to migrate from place of their formation to another one where accumulated. Levorsen (1967) reported the reasons behind this phenomenon. Many criteria were used to check up the hydrocarbon migrations. In the present study; Pristane (Pr) / Phytane (Phy), $\mathrm{Pr} / \mathrm{C}_{17}, \mathrm{Phy} / \mathrm{C}_{18}$, and Carbon Preference Index (CPI) were employed. Owing to Didyke (1978) cited in Salman, (2003) the low value of Pr/Phy ratio (less than one) confirms the migration of Yamama organic matter, and the reducing conditions under which these organic materials have been deposited. Furthermore, the low value of $\mathrm{Pr} / \mathrm{C}_{17}$ and $\mathrm{Phy} / \mathrm{C}_{18}$ attributed to the fractionation of Hydrocarbons accompanied with the faster expulsion of low molecular weight hydrocarbon relative to those of high molecular weight (Leythaeuser et al., 1984). The Yamama hydrocarbon migration occurred from the matured source rocks at depth below $3800 \mathrm{~m}$ toward the northwest of WQ-field in accord with the increases in the mature sediments. The order of hydrocarbon component migration is; $\mathrm{C}_{17}, \mathrm{C}_{18}$, pristane, and phytane (Salman, 2003). Regarding CPI, Bary and Evans (1965), Tissot and Welte (1978), and Hunt (1979) agree that the mature sediments exhibit low CPI value(less than one). Table (2) shows low value for CPI (0.91-1.0) which elucidates the maturation of the organic matters of Yamama Formation in WQ-field. 
Fig.4: The relationship between petroleum potential (PP) and total organic carbon (TOC) in Yamama rocks at West Qurna field.

Table 2: The results of saturated hydrocarbons analyses of Yamama core samples by column chromatography.

\begin{tabular}{|l|l|l|l|}
\hline \multicolumn{1}{|c|}{ Well No. } & $\mathbf{1}$ & $\mathbf{2}$ & $\mathbf{3}$ \\
\hline Pristane & & & \\
\hline Phytane & 0.7 & 1.034 & 0.76 \\
\hline CPI & 1.26 & 1.84 & 2.82 \\
\hline Pr/Phy & 0.91 & 0.95 & 1.0 \\
\hline Pr/C17 & 0.55 & 0.698 & 0.26 \\
\hline Phy/C18 & 0.1772 & 0.1816 & 0.1827 \\
\hline
\end{tabular}




\section{CONCLUSIONS}

From the results of Yamama organic matters study the following conclusions can be drawn:

-The color variations of Yamamama core samples are attributed to the variations in their organic matter contents.

-The organic matter of Yamama Formation is mainly consisting of type-II with subordinate amount of type-III kerogen.

-TOC and CPI parameters showed that Yamama organic matter reachs an advance stage of thermal maturation except at depth below3700m where maturation exceeded the catagensis stage leading to the formation of pyrobituminous layer with variable thickness. -Although Yamama Formation represents a good reservoir, the HI and P.P parameters also proved that this formation in W Q-field represents source rocks with good to very good properties.

-Pri/Phy. Ratio indicates that Ymamam Formation were deposited under reducing conditions, and the northwset trend of hydrocarbon migration

\section{REFERENCES}

Al-Marsoumi, A.M.H., Al-Mohamed, R.A.H., and Hmood, H.G.F., 2003. Mineralogy and Geochemistry of Yamama Formation (Late Beirriasian- Early Valangian) Southern Iraq. Iraqi Jour. Geol. Sci., Vol.3, No.1, pp.11-29.

Al-Sakini, J., 1992. Geology of Iraqi and Middle East petroleum in Summary. North Oil company Publication, 173p. (in Arabic).

Banerjee, A.M., and Sharma, A.K., 2002. Modern Geochemical Tools for Explorations, www. Geochemistry books.

Bary, E.E., and Evans, E.D., 1965. Hydrocarbons in Nonreservoir Rocks Source Rocks Beds, Part I. Am. Assoc. Pet. Geol. Bull., Vol.49, pp.248-257.

Basken, D.K., 1997. AtomicH/C Ratio of Kerogen as an Estimate of Thermal Maturity and Organic matter Conversion. Am. Assoc. Pet.Geol., Vol.81, No.9 (Sep. 1997), pp.1473-1450.

Buday, T., 1980. The Regional Geology of Iraq, Vol. 1, Stratigraphy and Palogeography (Kassab, I., and Jassim, S. Z. ed.), Dar Al-Kutib, Mosul Univ., 495p.

Buday, T., and Jassim, S.Z., 1987. The Regional Geology of Iraq, Vol.2, Tectonic and Structure, Kassab, I.I.M. (ed.), Dar Al-Kutib, Mosul Univ., 354p.

Didyke,

Espitalie, J., 1986. Use of Tmax as a maturation index for different types of organic matter comparison with vitrinite reflectance in; Thermal Modeling in Sedimentary Basins (edd J. Burrus) ed. Techmip, Paris, pp.475-469.

Hunt, J.M., 1979. Petroleum Geochemistry and Geology, Freeman, San Francisco, 617p.

Langford, F.F and Blance-Valleron, M.M., 1990. Interpretation rock-eval, pyrolysis data using graphs of pyrolize abe by hydrocarbons V, S. Total Organic Carbon. Am. Assoc. Pet. Geol. Bull. Vol. 74, pp.799-804.

Levorsen, A.I., 1967. Geology of Petroleum, 2nd ed., Freeman, San Francisco, 724p.

Pratt, L.M., 1984. Influence of Paleo-Environment Factors on the Preservation of Organic matter in Middle Cretaceous, Greenhorn Formation, Pueblo, Colorado. Am. Assoc. Pet. Geol. Bull., Vol.68, pp.1148-1159. 
Rulkotter, J., Welte, D.H. and Schaefer, R.G., 1984, b ،Geochemistry and Petrography of Organic Matter in Sediments From Sites 545 and 547 DSDP., Washington, Vol. 1xxx1x, pp.775-806.

Salman, A.W.D., 2003. Organic Geochemical Study of Yamama Formation in West Qurna Oil Field Southern Iraq, Unpubl. M.Sc. Theses, Basrah University, 110p., (in Arabic).

Tissot, B.P. and Welte, D.H., 1978. Petroleum Formation and Occurrence, a new approach to oil and gas exploration, 2nd Ed., Springer-Verlag, Berlin, 587p.

Ungerer, P., Bessis, F., Chent, P.Y., Durand, B., Nogaret, E., Chiarelli, A., Oudin, J.I., and Perrin, J., 1984. Geological and geochemical models in Oil Exploration, Principles and Practical examples; Institute Francais du Petrol, France, 24p.

Van Bellen, R.C., Dunnington, H.V., Wetzel, R., and Morton, D.M., 1959. Lexique Stratigraphic International Asia, Iraq, Congress Geol. International Commission de Stratigraphique, Vol. III, Fasc.10a, Iraq, Paris, 333p. 